\title{
Analysis of Migration and Rangeland Management and Feasibility of Its Outsourcing to Nomadic Organizations of Tehran Province (A case study of system in the Lar-Varamin ecosystem)
}

\author{
Rahman Sharifi \\ Agricultural Research and Instruction and Natural Resources Center of Tehran Province, \\ Agricultural Research, Education and Extension Organization (AREEO) \\ Email: R_sharifi46@gmail.com \\ Habibollah Mahdavivafa \\ Agricultural Research and Instruction and Natural Resources Center of Tehran Province, \\ Agricultural Research, Education and Extension Organization (AREEO) \\ Email: hmahdavi2000@gmail.com \\ Ebrahim Farahani \\ Agricultural Research and Instruction and Natural Resources Center of Tehran Province, \\ Agricultural Research, Education and Extension Organization (AREEO) \\ Ali Mohebbi \\ Research Institute of Forests and Rangelands, \\ Agricultural Research Education and Extension Organization(AREEO)
}

Abstract: Migration has been in the nomadic husbandry system for a long time, and outsourcing of this responsibility to the nomads and providing them with a role in this matter can be one of the ways to overcome the inadequate and inefficient state nomadic migration management system. Therefore, the Nomads Affairs Organization, Research Institute of Forests and Rangelands, and the National Forests, Range and Watershed Management Organization emphasized on the research-based approach on this matter and after numerous meetings for relevant experts and nomads of Varamin-Lar ecosystem, considering the severity of the problems of migration, the representatives were elected and introduced by a majority vote of nomads to pursue affairs in their respective customary systems. For this purpose, four customary systems of Dahaneh-Sang, Chehel-Barreh, Kamar-Dashet-vasat, Moghsar, and Yordgiedar were selected as pilots in Lar plain. The highlands of these pilots were Tuchal village in Pakdasht, Varamin. Evaluation analysis highlighted important rangeland management indicators such as capacity, status, tendency and percentage of utilization. Therefore, the results of the performance evaluation of the nomads' representatives during the study also showed that about $50 \%$ of the representatives' management decisions including the foundation of organizations, revision or preparation of multifunctional rangeland plans, the implementation of the water supply project and the anti-tick bath in the highland, observing the migration calendar, employing the guards, revitalizing the spirit of cooperation and empathy among the tribes and empowering the nomads of the region were met which resulted in better grazing management and improved vegetation than before the project was implemented. The reason for the failure of the remaining $50 \%$ of their decisions was due to the lack of serious will of the National Forests, Rangeland and Watershed Organization to outsource the management to the nomads and the management conflicts between the department of environment and the nomads in the region, as well as the lack of government support credits for the nomads. Investigation of the overall results of Tuchal village (highland) showed that due to perishable exploitation of rangelands of highland and a large number of livestock grazers and exploiters and not observing the grazing rate based on grazing licenses and some reduction of rangelands of this village due to change in its use, the management in this village was not successful. However, due to the co-operation of the locals to guard some of the rangelands, in $\mathbf{2 0 1 8}$, an increase in vegetation percentage before grazing, forage production, vegetation percentage after grazing, residual production after grazing and a decrease in capacity and dry forage exploitation rates after grazing were observed. 
Keywords: Feasibility, Migration Management, Rangeland exploitation, Nomadic organizations, Lar - Varamin ecosystem, Tehran province.

\section{Introduction:}

Valuable steps have been taken to improve the condition of rangelands and natural resources in the years following the Islamic Revolution, demonstrating the understanding of the situation of natural resources and various approaches for resolving natural resource. As a result, studies and planning have been done which resulted in codification and implementation of laws including the implementation of rangelands and livestock plans, which may have had many positive effects, but perhaps due to some managerial-executive problems were not fully successful. One of the reasons for this failure was the socio-economic issues, especially the poor participation of nomads in the process of implementing the plans. On the other hand, due to the indigenous knowledge and deep knowledge of the nomadic tribal communities on the rangelands exploited and the paths of their customary ways and territories, the participation of this stratum of society (nomadic tribes), the nomadic organizations, in particular, can have a significant impact on the management and organization of the migration and rangelands. Because the participation of the community stratum for which plans and programs are implemented will be effective in reducing economic, social, and even environmental problems and they would have a sense of belonging and. Therefore, this study presents the feasibility of outsourcing nomadic and migration management to nomadic organizations to provide appropriate participatory management practices. Since the beginning of the forties, the government has been responsible for managing nomadic migrations and rangelands and the nomads were annually asked to migrate based on the calendar presented by natural resources organization. The migration calendar is planned without any consultation with the nomads at a nearly constant date, and the weather, precipitation, or drought and other environmental and socio-economic factors do not affect the calendar. Ignoring the role of the exploiters and the lack of attention to the situations in relevant planning on the one hand and the lack of sufficient facilities in the government on the other hand have caused many nomads to encounter numerous problems during the migration, some of which waiting behind the entrance of rangelands, lack of planning to provide long-term service for them, lack of water and forage, accumulation of human and animal populations, and the nomadic livestock being grazed by the villagers and above all, that the executive systems do not usually take responsibility. Therefore, the purpose of this study is to answer the fundamental question of the possibility of assigning nomadic and rangeland management to the nomads themselves in order to implement the most appropriate management style for planning, migration, exploitation, and management of rangelands in Lar-Varamin ecosystem.

\section{Some of the research literature is as follows:}

- Ghorbani et al. (2012) in a study entitled "A New Approach in Policy Making and Planning for Collaborative Management of Natural Resources" concluded that the two veterinary departments and the village council considering a high density of trust and partnership with rangeland users, can play a key role in rangeland policymaking. Statistical analysis showed a 70\% correlation between trust and partnership between institutions and rangeland users (1).

- Bozorgi and Ghorbani (2014) in Stakeholder Analysis Addressed the Social Power, and Network Analysis in the Participatory Management of Natural Resources in the Narian Rural Community Rangelands in Taleghan Central Region as key players in the Narian Rangelands Cooperative Management (2).

- Abedi Sarvestani (2014), in the study of the early nomadic spring migration of Fars province nomads, concluded that the most important factor in nomadic early migration is lack of water and forage for livestock. Protecting the nomadic routes, appointing guards for the rangelands, increasing the security of the nomadic migration, creating temporary enclosures along the nomadic route to support livestock services, providing water for nomads with appropriate methods and providing part of the forage needed over the drought years are of the research proposals for controlling the early nomadic migration (3).

- Yousefi, Mohsen and Behbahani, Niloufar (2014) in Implementing Sustainable Natural Resources Management Plan Based on Local Community Participation Described the Role of Local Communities in Sustainable Natural Resources Management (Successful International Project - RFLDL South Khorasan, Sarayan) and Stated that the local community-based management is an appropriate approach for the sustainability of natural resources (4).

Plummer and Fitzgibbon. (2004) see the framework of collaborative management as context, agreement and link mechanism (6).

Bied-Charreton et al., (2006): In many developing countries, there are various organizations irrelevant to solving the identified problems. This instability has led to the fragmentation of natural resource management. Existing laws have also ignored local standards, so lack of clear rules has left beneficiaries with free access to these resources, and also have encouraged profitable individuals seeking to take advantage of others' efforts to express opportunistic behaviors. The lack of explicit laws on participatory management has led to a lack of coordination among responsible organizations. The reason for the ineffectiveness of participatory management is the lack of 
democratic, organizational and grassroots foundations alongside politically disruptive guidelines that disintegrate this type of management after removing external credits from the project (7).

Ostrom (2007) believes that there is no effective single solution to complex problems. An important issue is how to organize a participatory project and the relationship between the central government and local communities (8).

- Nelson and Agrawal (2008), based on studies in African countries of Botswana, Kenya, Mozambique, Tanzania, Zambia, and Zimbabwe, stated that the willingness to outsource government management to local communities is correlated with the amount of outcome of political powers. Despite the pressure of international institutions to implement projects, the central powers continue to maintain their control over natural resources. At times, local communities see project implementation as an opportunity to receive money such as state grants. So this partnership will not be a real partnership. This type of cooperation will lead to severe destruction of resources (9).

Randrianalijaona (2008) in Madagascar has shown that participatory projects are successful in creating channels for the income of local peoples, so they would not need external credits and the project would continue (10).

Area of study:

Area of the Lar watershed: 73,000 hectares, $84 \mathrm{~km}$ northeast of Tehran city which is restricted to Qaddan, Kaboud and Sorkhak mountains from the north, to Lavasanat area and part of Jajrood river from the south, to Karaj and Jajrood watershed from the west and Damavand and Pleur Mountains from east. Latitude: Located between 36 degrees, 41 minutes and 35 seconds to 35 degrees, 48 minutes and 40 seconds, and longitude: between 51 degrees and 32 minutes to 52 degrees and 04 minutes.

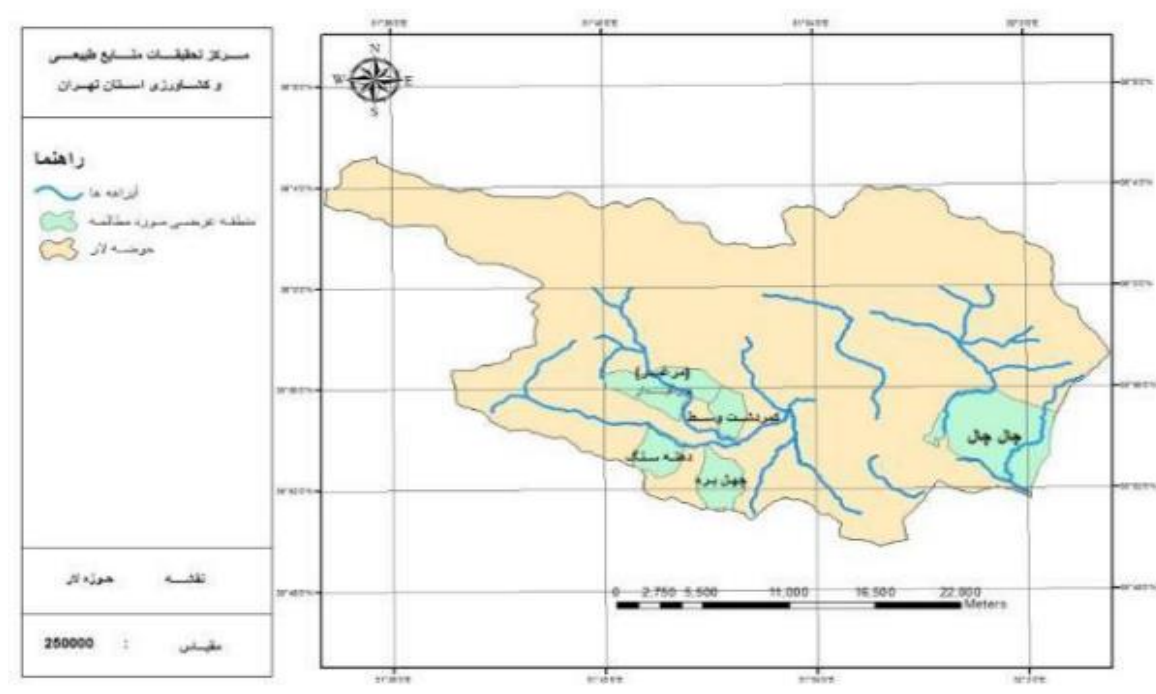

Map of the geographic location of Lar plain and selected systems

Reference: Sharifi, Rahman et al., 2018. (10).

The four systems all have grazing licenses that have been audited since 1990. In these systems, 21 of the exploiters have died, which are still on the list. About 30 percent of exploiters of Yurdgeydar and Morghsar do not own livestock. In the Yurdgeydar and Mogharsar system, $13 \%$ and the Kamardashe-vasat system $45 \%$ of the exploiters do not have a grazing license (Table 1).

Table 1: Farmers Listed on issued Grazing licenses in high land/lowland/middle land

\begin{tabular}{|c|c|c|}
\hline \multirow{2}{*}{ System name } & \multicolumn{2}{|c|}{ People holding grazing license } \\
\cline { 2 - 3 } & number & percentage \\
\hline Yurdgeydar and Mogharsar & 18 & 100 \\
\hline Chehel-bareh & 13 & 100 \\
\hline Kamardashte-vasat & 6 & 70 \\
\hline Dahaneh-sang & 6 & 100 \\
\hline Tuchal village (High land) & 184 & - \\
\hline
\end{tabular}

Reference: Sharifi, Rahman et al., 2018. (10). 
Table 2: Pasture plan livestock or grazing licenses issued in thelowland of Lar

\begin{tabular}{|c|c|c|c|c|c|c|c|}
\hline \multirow{3}{*}{ System name } & \multicolumn{4}{|c|}{$\begin{array}{l}\text { Number of livestock specified in grazing } \\
\text { license (livestock unit) }\end{array}$} & \multicolumn{3}{|c|}{$\begin{array}{lll}\begin{array}{l}\text { Current livestock } \\
\text { (livestock unit) }\end{array} & \text { number } \\
\end{array}$} \\
\hline & \multirow[t]{2}{*}{ Allowed } & \multirow[t]{2}{*}{ Existed } & \multicolumn{2}{|l|}{ Excess } & \multirow[t]{2}{*}{ Existed } & \multicolumn{2}{|c|}{$\begin{array}{l}\text { Excess of the issued } \\
\text { allowed number on the } \\
\text { license }\end{array}$} \\
\hline & & & Number & Percentage & & Number & Percentage \\
\hline Chehel-bareh & 1846 & 2209 & 363 & 20 & 2500 & 645 & 34 \\
\hline Dahaneh-sang & 1020 & 1805 & 785 & 76 & 1400 & 380 & 37 \\
\hline $\begin{array}{l}\text { Kamardashte- } \\
\text { vasat }\end{array}$ & 550 & 955 & 405 & 82 & 1300 & 750 & 136 \\
\hline $\begin{array}{l}\text { Yurdgeydar and } \\
\text { Mogharsar }\end{array}$ & 1950 & 3198 & 1248 & 64 & 4550 & 2600 & 133 \\
\hline Total & 5366 & 8167 & 2801 & 52 & 8750 & 4375 & 82 \\
\hline
\end{tabular}

Reference: Sharifi, Rahman et al., 2018. (10).

\section{Research Methodology:}

An overview of the overall results of the Morghsar and Yurdgeydar customary system showed that, especially in the last two years of the project, the nomads of this system, with respect to the time of entry and exit announced by the executive department and observance of the grazing rate based on the grazing license, cooperated with the General Directorate of Natural Resources on not entering excess livestock and the use of guards and the not entering other livestock and with the support and support of nomads affairs management have been able to reduce grazing rate so vegetation percentage before grazing, before forage production, vegetation percentage after grazing, residual production and capacity in the traditional System of Mogharsar and Yurdageydar in the last two years of the project were increased and the percentage of the exploitation was decreased. So the nomads of this system were able to manage their rangelands relatively well in two years of 2017 and 2108 (Table 3).

Table 3: Comparison table of average vegetation cover parameters, production, and capacity in Morghsar and Yurdageydar system

\begin{tabular}{lllllll}
\hline Years & \multicolumn{6}{l}{ Parameters average } \\
\cline { 2 - 7 } & $\begin{array}{l}\text { Vegetation } \\
\text { cover before } \\
\text { grazing (\%) }\end{array}$ & $\begin{array}{l}\text { Production } \\
(\mathrm{kg})\end{array}$ & $\begin{array}{l}\text { Vegetation } \\
\text { cover after } \\
\text { grazing (\%) }\end{array}$ & $\begin{array}{l}\text { Residual } \\
\text { production } \\
(\mathrm{kg})\end{array}$ & $\begin{array}{l}\text { Exploitation } \\
\text { percentage } \\
(\%)\end{array}$ & $\begin{array}{l}\text { Capacity } \\
\text { (livestock } \\
\text { unite) }\end{array}$ \\
\hline 2015 & $36 / 00^{\mathrm{b}}$ & $115 / 0^{\mathrm{a}}$ & $3 / 0^{\mathrm{bc}}$ & $6 / 2^{\mathrm{bc}}$ & $94 / 2^{\mathrm{b}}$ & $0 / 85^{\mathrm{a}}$ \\
2016 & $39 / 00^{\text {ab }}$ & $120 / 0^{\mathrm{a}}$ & $1 / 4^{\mathrm{c}}$ & $3 / 0^{\mathrm{c}}$ & $97 / 4^{\mathrm{a}}$ & $0 / 89^{\mathrm{a}}$ \\
2017 & $41 / 00^{\mathrm{ab}}$ & $124 / 0^{\mathrm{a}}$ & $4 / 0^{\mathrm{b}}$ & $7 / 0^{\mathrm{b}}$ & $94 / 3^{\mathrm{b}}$ & $0 / 92^{\mathrm{a}}$ \\
2018 & $47 / 00^{\mathrm{a}}$ & $139 / 0^{\mathrm{a}}$ & $6 / 2^{\mathrm{a}}$ & $11.0^{\mathrm{a}}$ & $92 / 2^{\mathrm{b}}$ & $1 / 03^{\mathrm{a}}$ \\
\hline
\end{tabular}

There was no significant difference in Duncan's test at the $5 \%$ level of probability between the averages that shared at least one letter.

Reference: Sharifi, Rahman et al., 2018. (5).

Also, an overview of the overall results of the Chehl-bareh customary system showed that, especially in the last two years of the project, the nomads of this system, with respect to the time of entry and exit announced by the executive department and observance of the grazing rate based on the grazing license, cooperated with the General Directorate of Natural Resources on not entering excess livestock and the use of guards and the not entering other livestock and with the support and support of nomads affairs management have been able to reduce grazing rate so vegetation percentage before grazing, before forage production, vegetation percentage after grazing, residual production and capacity in the traditional System of Chehel-bareh in the last two years of the project were increased and the percentage of the exploitation was decreased. So the nomads of this system were able to manage their rangelands relatively well in two years of 2017 and 2108 (Table 4). 
Table 4: Comparison table of average vegetation cover parameters, production, and capacity in Chehel-bareh system

\begin{tabular}{lllllll}
\hline Years & \multicolumn{6}{l}{ Parameters average } \\
\cline { 2 - 6 } & $\begin{array}{l}\text { Vegetation } \\
\text { cover before } \\
\text { grazing (\%) }\end{array}$ & $\begin{array}{l}\text { Production } \\
(\mathrm{kg})\end{array}$ & $\begin{array}{l}\text { Vegetation } \\
\text { cover after } \\
\text { grazing (\%) }\end{array}$ & $\begin{array}{l}\text { Residual } \\
\text { production } \\
(\mathrm{kg})\end{array}$ & $\begin{array}{l}\text { Exploitation } \\
\text { percentage } \\
(\%)\end{array}$ & $\begin{array}{l}\text { Capacity } \\
\text { (livestock } \\
\text { unite) }\end{array}$ \\
\hline 2015 & $41 / 00^{\mathrm{a}}$ & $127 / 0^{\mathrm{b}}$ & $6 / 6^{\mathrm{b}}$ & $10 / 0^{\mathrm{b}}$ & $92 / 2^{\mathrm{b}}$ & $0 / 94^{\mathrm{b}}$ \\
2016 & $44 / 00^{\mathrm{a}}$ & $137 / 0^{\mathrm{ab}}$ & $4 / 2^{\mathrm{c}}$ & $7 / 0^{\mathrm{b}}$ & $94 / 9^{\mathrm{a}}$ & $1 / 01^{\mathrm{ab}}$ \\
2017 & $39 / 00^{\mathrm{a}}$ & $123 / 0^{\mathrm{b}}$ & $4 / 8^{\mathrm{c}}$ & $9 / 0^{\mathrm{b}}$ & $92 / 8^{\mathrm{b}}$ & $0 / 91^{\mathrm{b}}$ \\
2018 & $47 / 00^{\mathrm{a}}$ & $147 / 0^{\mathrm{a}}$ & $9 / 0^{\mathrm{a}}$ & $17 / 0^{\mathrm{a}}$ & $88 / 3^{\mathrm{c}}$ & $1 / 09^{\mathrm{a}}$ \\
\hline
\end{tabular}

There was no significant difference in Duncan's test at the $5 \%$ level of probability between the averages that shared at least one letter.

Reference: Sharifi, Rahman et al., 2018. (5).

Also, an overview of the overall results of the Kamardashte-vasat customary system showed that, especially in the last two years of the project, the nomads of this system, with respect to the time of entry and exit announced by the executive department and observance of the grazing rate based on the grazing license, cooperated with the General Directorate of Natural Resources on not entering excess livestock and the use of guards and the not entering other livestock and with the support and support of nomads affairs management have been able to reduce grazing rate so vegetation percentage before grazing, before forage production, vegetation percentage after grazing, residual production and capacity in the traditional System of Kamardashte-vasat in the last two years of the project were increased and the percentage of the exploitation was decreased. So the nomads of this system were able to manage their rangelands relatively well in two years of 2017 and 2108 (Table 5).

Table 5: Comparison table of average vegetation cover parameters, production, and capacity in Kamardashte-vasat system

\begin{tabular}{|c|c|c|c|c|c|c|}
\hline \multirow[t]{2}{*}{ Years } & \multicolumn{6}{|c|}{ Parameters average } \\
\hline & $\begin{array}{l}\text { Vegetation } \\
\text { cover before } \\
\text { grazing (\%) }\end{array}$ & $\begin{array}{l}\text { Production } \\
\text { (kg) }\end{array}$ & $\begin{array}{l}\text { Vegetation } \\
\text { cover after } \\
\text { grazing (\%) }\end{array}$ & $\begin{array}{l}\text { Residual } \\
\text { production } \\
(\mathrm{kg})\end{array}$ & $\begin{array}{l}\text { Exploitation } \\
\text { percentage } \\
(\%)\end{array}$ & $\begin{array}{l}\text { Capacity } \\
\text { (livestock } \\
\text { unite) }\end{array}$ \\
\hline 2015 & $48 / 00^{a}$ & $136 / 0^{a}$ & $5 / 0^{a}$ & $9 / 4^{a}$ & $92 / 9^{b}$ & $0 / 91^{a}$ \\
\hline 2016 & $51 / 00^{a}$ & $140 / 0^{\mathrm{a}}$ & $1 / 8^{b}$ & $3 / 0^{b}$ & $97 / 8^{a}$ & $0 / 93^{a}$ \\
\hline 2017 & $37 / 00^{b}$ & $107 / 0^{b}$ & $2 / 0^{b}$ & $4 / 0^{b}$ & $96 / 3^{a}$ & $0 / 72^{b}$ \\
\hline 2018 & $53 / 00^{a}$ & $151 / 0^{a}$ & $5 / 0^{a}$ & $9 / 6^{\text {a }}$ & $93 / 6^{b}$ & $1 / 01^{a}$ \\
\hline
\end{tabular}

There was no significant difference in Duncan's test at the $5 \%$ level of probability between the averages that shared at least one letter.

Reference: Sharifi, Rahman et al., 2018. (5).

At the end, an overview of the overall results of the Dahaneh-sang customary system showed that, especially in the last two years of the project, the nomads of this system, with respect to the time of entry and exit announced by the executive department and observance of the grazing rate based on the grazing license, cooperated with the General Directorate of Natural Resources on not entering excess livestock and the use of guards and the not entering other livestock and with the support and support of nomads affairs management have been able to reduce grazing rate so vegetation percentage before grazing, before forage production, vegetation percentage after grazing, residual production and capacity in the traditional System of Dahaneh-sang in the last two years of the project were increased and the percentage of the exploitation was decreased. So the nomads of this system were able to manage their rangelands relatively well in two years of 2017 and 2108 (Table 6). 
Table 6: Comparison table of average vegetation cover parameters, production, and capacity in Dahaneh-sang system

\begin{tabular}{lllllll}
\hline Years & \multicolumn{6}{l}{ Parameters average } \\
\cline { 2 - 7 } & $\begin{array}{l}\text { Vegetation } \\
\text { cover before } \\
\text { grazing (\%) }\end{array}$ & $\begin{array}{l}\text { Production } \\
(\mathrm{kg})\end{array}$ & $\begin{array}{l}\text { Vegetation } \\
\text { cover after } \\
\text { grazing }(\%)\end{array}$ & $\begin{array}{l}\text { Residual } \\
\text { production } \\
(\mathrm{kg})\end{array}$ & $\begin{array}{l}\text { Exploitation } \\
\text { percentage } \\
(\%)\end{array}$ & $\begin{array}{l}\text { Capacity } \\
\text { (livestock } \\
\text { unite) }\end{array}$ \\
\hline 2015 & $54 / 00^{\mathrm{a}}$ & $151 / 0^{\mathrm{a}}$ & $6 / 6^{\mathrm{b}}$ & $12 / 0^{\mathrm{b}}$ & $92 / 1^{\mathrm{a}}$ & $1 / 12^{\mathrm{a}}$ \\
2016 & $56 / 00^{\mathrm{a}}$ & $160 / 0^{\mathrm{a}}$ & $7 / 2^{\mathrm{ab}}$ & $13 / 0^{\mathrm{ab}}$ & $91 / 9^{\mathrm{a}}$ & $1 / 18^{\mathrm{a}}$ \\
2017 & $52 / 00^{\mathrm{a}}$ & $155 / 0^{\mathrm{a}}$ & $8 / 0^{\mathrm{ab}}$ & $15 / 0^{\mathrm{ab}}$ & $90 / 3^{\mathrm{a}}$ & $1 / 15^{\mathrm{a}}$ \\
2018 & $58 / 00^{\mathrm{a}}$ & $170 / 0^{\mathrm{a}}$ & $9 / 0^{\mathrm{a}}$ & $17 / 0^{\mathrm{a}}$ & $90 / 0^{\mathrm{a}}$ & $1 / 26^{\mathrm{a}}$ \\
\hline
\end{tabular}

There was no significant difference in Duncan's test at the $5 \%$ level of probability between the averages that shared at least one letter.

Reference: Sharifi, Rahman et al., 2018. (5).

\section{Discussion and Conclusion:}

June 15th is considered as the date for the entry into the plain of Lar and rangeland management in grazing licenses which is approved by most nomad tribes in the area. Also in this area (Lar plain) due to the high sensitivity of area, the date of livestock entry is specified with coordination of representatives of Lar tribes with Tehran Governorate, Tehran Province Jihad Organization, Tehran Province Directorate of Watershed Management and Natural Resources and Tehran Province Environment Organization in each specific year and all tribes adhere to it. This date can usually be delayed up to 10 to 15 days each year due to rainfall and vegetation status. In speaking to tribal representatives of the four systems the announced date has been endorsed by them.

Investigations show that in 2016 the early grazing was not observed in Lar plain and also in Tochal village by four systems in highland. In all systems, the grazing capacity was based on grazing licenses. Pasture assignment to unlicensed rancher was seen in one system (Chehel-bareh) and no pasture assignment to unlicensed rancher was observed in other systems. A rancher with no grazing license was observed in one system (Kamardashtevasat). Renting the licenses to others was reported only in one system (Chehel-bareh). None of the systems delayed leaving the ranch. In these systems did the table renewal, rangeland planning, rangeland plan review, rangeland management, and rangeland remediation were not done.

Investigations also show that in 2016 the early grazing was not observed in four systems in Lar plain and also in Tochal village in highland. In all systems, the grazing capacity based on grazing licenses was observed. Pasture assignment to unlicensed rancher was seen in systems and no pasture assignment to unlicensed rancher was observed in other systems. Rancher with no grazing license was not observed in systems. Renting the licenses to others was not reported in systems. None of the systems delayed leaving the ranch. In these systems, the table renewal, rangeland planning, rangeland plan review were not done. Rangeland management and rangeland remediation measures have not been implemented in the systems, but in some areas of Tochal village, enclosure operations have been carried out.

Based on the measurements taken in these four systems, it was shown that: In the Dahane-sang system, the condition of this type was medium and its orientation was constant. The total production of this type was 758 $\mathrm{kg} / \mathrm{ha}$, which according to the allowable harvest coefficient and the preference value the allowable exploited forage amount was $159.3 \mathrm{~kg} / \mathrm{ha}$. The livestock capacity of this type was 3.12 livestock units per month and 1.3 livestock units in 3 months. Based on the measurements made in the Chehe-bareh system, the status of this type was medium and its orientation was constant. The total production of this type was $547 \mathrm{~kg} / \mathrm{ha}$, which according to the allowable harvest coefficient and preference value the allowable exploited forage amount was $137 \mathrm{~kg} / \mathrm{ha}$. The livestock capacity of this type was 2.69 units per hectare per month. Approximately 0.9 units of livestock per hectare can be grazed in 3 months. Based on the measurements made in the Kamardashte-vasat system, the status of this medium type was constant and its orientation was constant. The total production of this type is 490 $\mathrm{kg} / \mathrm{ha}$ which according to the allowable harvest coefficient and preference value the allowable exploited forge amount was $120 \mathrm{~kg} / \mathrm{ha}$. The livestock capacity of this type was 2.75 units per hectare per month. Approximately 0.9 units of livestock per hectare can be grazed in 3 months. Based on the measurements taken, the system of this type of medium and its tendency is constant. The total production of this type is $520 \mathrm{~kg}$ ha- 1 which according to the allowable harvest coefficient and the preference value of its allowable forage is $134.4 \mathrm{~kg}$-ha- 1 . The livestock capacity of this type is 2.6 units per hectare/month. Approximately 0.87 units of livestock per hectare can be grazed in 3 months. Based on the measurements made in Yordgeydar and Morghsar system, the status of this type was medium and its orientation was constant. The total production of this type was $520 \mathrm{~kg} / \mathrm{ha}$, which according to the allowable harvest coefficient and preference value the allowable exploited forage 
amount was $132.4 \mathrm{~kg} / \mathrm{ha}$. The livestock capacity of this type was 6.2 units per hectare per month. Approximately 0.87 units of livestock per hectare can be grazed in 3 months. According to the results obtained from the rangelands of Tochal va Dah Emam village customary system, the status of this type was poor and its orientation was negative. Forage production in this type relies on Darmaneh and Shaldem. Total harvestable forage production was measured at $291 \mathrm{~kg}$ ha- 1 which according to the allowable harvest coefficient and preference value the allowable exploited forage amount was $80 \mathrm{~kg}$ ha- 1 . The livestock capacity of this type was 1.7 units per hectare per month. Approximately 0.53 units of livestock per hectare can be grazed in 105 days. According to the results obtained from the analysis of variance in the Dahaneh-Sang customary system, it was found that the percentage of vegetation after grazing and residual production was affected by the years 2015, 2016, 2017 and 2018 and resulted in a significant difference in probability level of 5\%. In Chehe-bareh customary production system, vegetation after grazing, residual production, exploitation percentage, and capacity were significantly different at $5 \%$ and $1 \%$ probability levels. In Kamardashteh-vasat customary system, the percentage of vegetation before grazing, production, vegetation after grazing, residual production, exploitation percentage, and capacity showed significant differences at $5 \%$ and $1 \%$ probability levels. There was a significant difference in the $5 \%$ and $1 \%$ probability levels in Morghsar and Yordgeydar customary system in the percentage of vegetation before grazing, vegetation after grazing, residual production and exploitation percentage. In Tochal village, the percentage of vegetation after grazing, residual production, exploitation percentage, and capacity were significantly different at the $5 \%$ probability level. Also, the results of evaluating the performance of nomads representatives during the study also showed that about $50 \%$ of the nomads' representatives' management decisions included foundation of organizations, revising or preparing multifunctional rangeland plans, implementing a water supply project and anti-tick bath in highland, observing the migration calendar, employing the guards, revitalizing the spirit of co-operation and empathy among the tribes, empowering the nomads of the region, etc., has resulted in better grazing management and improved vegetation coverage comparing before the project. The reason for the failure of the remaining $50 \%$ of their decisions is the lack of serious will of the National Forests, Rangelands and Watershed Organization to assign the management to the nomads themselves and the management conflicts between the department of environment and the nomads in the region, as well as the lack of government support credits for the nomads. Investigation of the overall results of Tochal village (highland) showed that due to perishable exploitation of highland rangelands and a large number of exploiters and local livestock grazers and not observing the grazing rate based on grazing licenses and reduction of rangelands of this village due to change in its use, the management has not been very successful, but due to the co-operation of the locals to guard some of the rangelands of the village, in 2018, an increase in vegetation percentage before grazing, forage production, vegetation percentage after grazing, residual production after grazing and capacity and a decrease in dry forge exploitation after grazing were observed.

\section{References:}

[1] Bozorgi, Meh Rood and Ghorbani, Mehdi (2014) Stakeholder Analysis, Social Power, and Network Analysis in Collaborative Management of Natural Resources, Ph.D. Thesis, School of Natural Resources, University of Tehran.

[2] Abedi Sarvestani, A., 2014. Study of Early Spring migration of Fars Nomads, Geographical Research Quarterly 29, No. 115, pp. 2742.

[3] Ghorbani, Mehdi, Azarnivand, Hossein, Mehrabi, Ali Akbar, Bastani, Susan, Jafari, Mohammad and Nayebi, Hooshang (2012) Social Network Analysis: A New Approach in Collaborative Management and Management of Natural Resources, Journal of Rangeland and Watershed Management, Volume 65, Number 4. 568-553.

[4] Yousefi, Mohsen and Behbahani, Niloufar (2014) Sustainable Management of Natural Resources Based on Local Community Participation (Successful International Project Experience - RFLDL South Khorasan, Sarayan) Article published at http://nrskh.ir/article

[5] Sharifi, Rahman et al., 1979. Evaluation of Migration and Rangeland Management Status and Feasibility of its outsourcing to Nomadic Foundations of Tehran Province (Lar-Varamin ecosystem), Agricultural Research Education and Extension Organization, Tehran.

[6] Bied-Charreton, M., Makkaoui, R., Petit, O., Requier-Desjardins, M., 2006. La gouvernance des ressources en eau dans les pays en développement : enjeux nationaux et globaux, Mondes en développement (34) 3 -135

[7] 7-Nelson, F., Agrawal, A., 2008. Patronage or Participation? Community-based Natural Resource Management Reform in SubSaharan Africa, Development and Change 39(4), 557-85.

[8] 8-Ostrom, E., 2007. A diagnostic approach for going beyond panaceas, Proceedings of the National Academy of Sciences 104(39), 15181-187

[9] 9-Ryan Plummer, R ., Fitzgibbon, J ( 2004 ) Co-management of Natural Resources: A Proposed Framework, Environmental Management, Volume 33, Issue 6, pp 876-885.

[10] 10-Randrianalijaona, T.M., 2008. Gestion communautaire des ressources naturelles et développement durable, PhD, University of Antananarivo. 